\title{
Utilization of Human Skin Equivalent in Research of Scabies Pathogenesis
}

\section{Pemanfaatan Human Skin Equivalent (HSE) dalam Penelitian Patogenesis Skabies}

\author{
Reqgi First Trasia \\ Bagian Parasitologi, Fakultas Kedokteran \\ Universitas Sultan Ageng Tirtayasa
}

\begin{abstract}
Scabies is a tropical disease that requires large-scale control. Research on the pathogenesis of scabies in Indonesia is still rare. Meanwhile, in tropical countries, studies related to the course of scabies have been done quite a lot, one of which is by using a human skin model. The purpose of writing this article is to discuss the use of human skin modeling technology in researching the course of scabies. Research using HSE demonstrated modulation of cytokine secretion, expression of cell adhesion molecules, and gene expression in response to the scabies mite extract molecule.

Keywords: skabies, human skin equivalent (HSE), patogenesis, neglected tropical disease

Abstrak

Skabies adalah penyakit tropis yang membutuhkan pengontrolan skala besar. Penelitian mengenai patogenesis skabies di Indonesia masih jarang dilakukan. Sementara, di negaranegara beriklim tropis, studi terkait perjalanan penyakit skabies ini sudah cukup banyak dikerjakan, salah satunya adalah dengan menggunakan model kulit manusia. Tujuan dari penulisan artikel ini adalah untuk membahas mengenai pemanfaatan teknologi model kulit manusia dalam meneliti perjalanan penyakit skabies. Penelitian menggunakan HSE menunjukkan modulasi sekresi sitokin, ekspresi molekul adhesi sel, dan ekspresi gen sebagai respons terhadap molekul ekstrak tungau skabies.
\end{abstract}

Kata kunci: skabies, human skin equivalent (HSE), patogenesis, neglected tropical disease

\section{PENDAHULUAN}

Skabies merupakan penyakit parasit akibat infestasi Sarcoptes scabiei. WHO menggolongkan penyakit ini ke dalam Neglected Tropical Disease (NTD) karena minimnya pengontrolan kasus dan upaya eliminasi.(WHO, 2017) Di Indonesia, prevalensi skabies pada sebuah pesantren di Jakarta Timur sebesar 51,6\%. (Ratnasari, 2015) Di masyarakat yang memiliki risiko tinggi skabies, seperti lingkungan padat penghuni, prevalensi dapat mencapai 80\%. (Kemenkes, 2017)

Penelitian mengenai patogenesis skabies di Indonesia masih jarang dilakukan. Sementara, di negara-negara beriklim tropis, studi terkait perjalanan penyakit skabies ini sudah cukup banyak dikerjakan, salah satunya adalah dengan menggunakan model kulit manusia. (Morgan, 2015) Human skin equivalents (HSE) adalah substitusi kulit yang terdiri atas stratum korneum serta keratinosit yang berproliferasi dan dermis yang terdiri atas fibroblas di dalam matriks kolagen yang memiliki properti kulit manusia. Morgan (2015) menggunakan HSE untuk mengidentifikasi respons fenotipik bawaan dan mempelajari ekspresi gen sebagai respons terhadap tungau hidup. HSE juga telah digunakan pada studi sebelumnya untuk menjelaskan aspek respons imun terhadap tungau agar lebih memahami kemampuan tungau dalam memodulasi respons inflamasi dan imun hospes.

Tujuan dari penulisan artikel ini adalah untuk membahas mengenai pemanfaatan teknologi model kulit manusia dalam meneliti perjalanan penyakit skabies. Dengan adanya tinjauan ini, diharapkan penelitian mengenai skabies baik dari segi penegakan diagnosis, 
pengenalan manifestasi klinis, dan pengobatannya dapat lebih berkembang. Hal ini sangat penting dalam rangka eliminasi skabies sebagai penyakit tropis yang terabaikan.

\section{METODE}

Penelusuran dilakukan pada bulan Juli 2020 di PubMed, Google scholar, Proquest, dan Science Direct. Kata penelusuran adalah "Human skin equivalent AND scabies". Kriteria inklusi artikel adalah berbahasa Inggris, terdapat informasi model kulit manusia dan skabies, artikel dipublikasikan pada tahun 2015-2019. Kriteria eksklusi adalah terdapat duplikasi dan tidak dapat diakses keseluruhan. Publikasi yang terpilih pada seleksi judul dan abstrak diekstrak menggunakan tabel format standar dan diolah menggunakan Microsoft Excel spreadsheet. Data yang diekstraksi berupa penulis, tahun publikasi, jurnal, dan kesimpulan. Hasil kemudian disampaikan secara kualitatif.

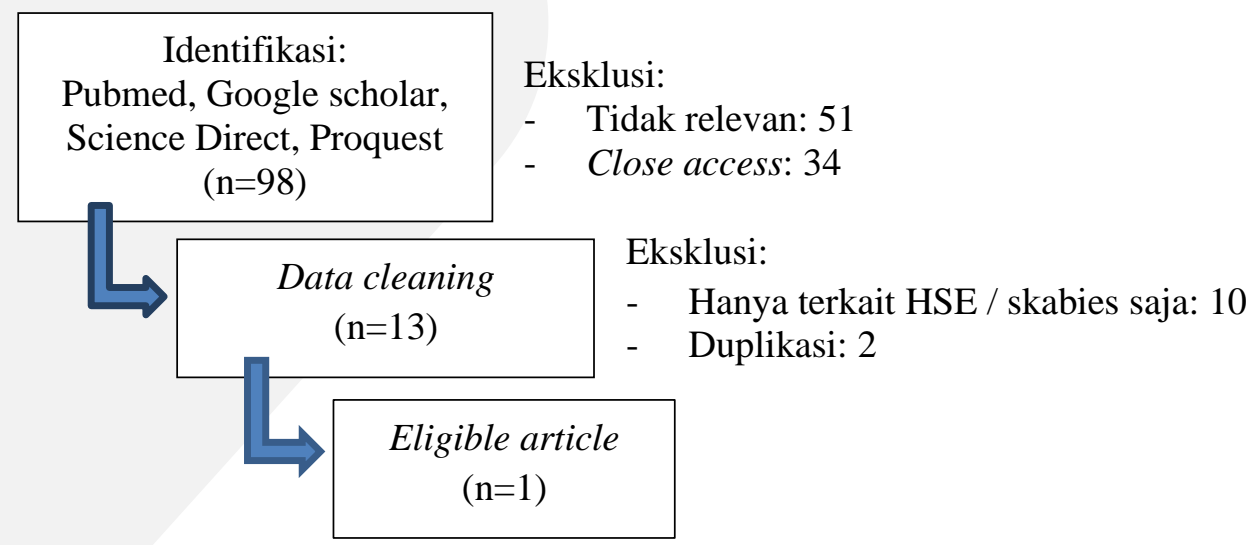

Gambar 1. Skema Proses Seleksi Artikel

Hasil penulusuran 98 artikel didapatkan satu artikel yang memenuhi kriteria inklusi dan eksklusi. Gambar 1 menunjukkan alur pemilihan artikel. Telaah kritis dilakukan terhadap satu artikel terpilih yang diterbitkan oleh jurnal kategori Q2 berdasarkan Scimago Journal and Country Rank.

\section{HASIL DAN PEMBAHASAN}

\section{Hasil}

Berdasarkan hasil telaah kritis terhadap artikel terpilih, diketahui bahwa peneliti dalam studi tersebut meletakkan tungau hidup di permukaan HSE. Tungau kemudian menggali dan masuk ke epidermis, lalu memicu perubahan ekspresi gen. Setelah 48 jam pasca-inokulasi, dari 25.800 gen yang diukur, 189 diantaranya mengalami up-regulation sedangkan 152 gen lainnya mengalami down-regulation. Untuk lebih jelasnya, akan disajikan pada gambar 2. 


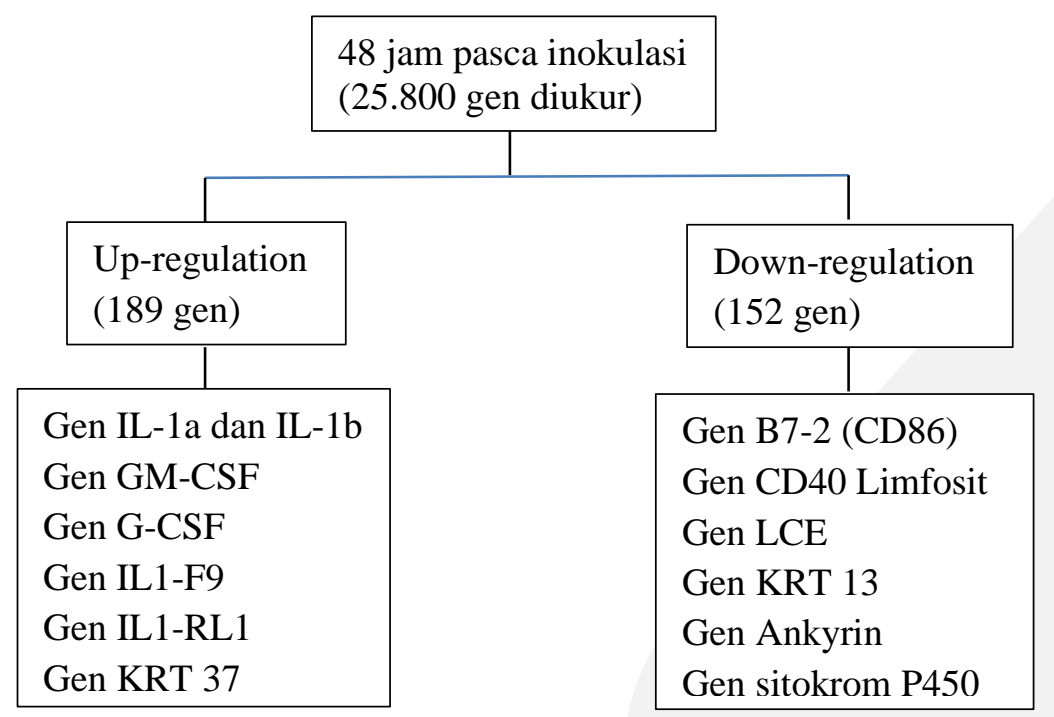

Gambar 2. Skema Hasil Modulasi Ekspresi Gen oleh Sarcoptes scabiei

\section{Pembahasan}

HSE memiliki properti fisik mirip epidermis dan dermis kulit manusia normal. Tungau skabies dapat menggali masuk ke dalam epidermis HSE sehingga kombinasi respons inflamasi dan imun bawaan dari keratinosit dan fibroblas serta interaksinya sebagai respons terhadap tungau hidup dan produknya seperti saliva dan feses dapat dipelajari menggunakan HSE.

Penelitian menggunakan kultur keratinosit epidermis manusia dan fibroblas dermis serta sel endotel mikrovaskulatur dermis menunjukkan modulasi sekresi sitokin dan ekspresi molekul adhesi sel sebagai respons terhadap molekul ekstrak tungau skabies. Di dalam studi tersebut sitokin dan molekul adhesi yang diukur dipilih karena berperan dalam respons imun dan inflamasi. Terdapat berbagai respons fenotipik terhadap tungau dan produknya namun studi tersebut tidak menentukan pengaruh tungau terhadap reseptor sitokin. Penggunaan monokultur sel dengan media cair memerlukan ekstrak yang terbuat dari badan tungau yang dihancurkan karena tungau hidup tidak dapat bertahan di dalam media kultur sel. Karena keterbatasan tersebut, Morgan et al (2015) menggunakan model kulit HSE untuk mempelajari sekresi sitokin dan ekspresi gen oleh sel kulit sebagai respons terhadap tungau hidup. Penggunaan HSE juga memungkinkan interaksi sel-ke-sel antara keratinosit epidermis dan fibroblas dermis layaknya dalam kondisi in vivo.

S.scabiei telah lama hidup bersama manusia dan mamalia lain serta berevolusi dan beradaptasi dengan berbagai mekanisme untuk menghindari respons imun hospes baik bawaan maupun didapat. Hospes menunjukkan respons imun tipe lambat terhadap skabies. Pada manusia, gejala klinis berupa inflamasi kulit baru timbul 4-8 minggu setelah terinfestasi. Respons imun yang lambat tersebut merupakan dampak dari kemampuan tungau dalam memodulasi berbagai aspek respons imun dan inflamasi hospes. (Sungkar S, 2016)

Sel epidermis seperti keratinosit dan sel langerhans merupakan sel pertama yang menghadapi tungau skabies dan produknya. Respons inflamasi bawaan dan didapat dari kulit hospes berperan sebagai pertahanan lini pertama terhadap invasi, kelangsungan hidup dan reproduksi tungau di dalam kulit. Tungau merangsang keratinosit dan sel dendritik melalui molekul yang terdapat di dalam telur, feses, ekskreta, saliva, dan cairan sekresi lain seperti enzim dan hormon, serta aktivitas organ tubuh seperti chelicerae, pedipalps dan kaki selama 
proses penggalian terowongan. Tubuh tungau mati yang membusuk juga merangsang respons imun. (Mellanby, 2014)

S.scabiei memproduksi banyak saliva saat membentuk terowongan dan merupakan sumber molekul yang dapat memodulasi inflamasi atau respons imun hospes. Produk tungau yang menembus dermis merangsang sel-sel seperti fibroblas, sel endotel mikrovaskular serta sel imun seperti sel langerhans, makrofag, sel mast dan limfosit. Diduga sel langerhans dan sel dendritik lain memproses antigen tungau dan membawa antigen tersebut ke jaringan limfe regional yaitu tempat respons imun didapat diinisiasi melalui aktivasi sel limfosit $\mathrm{T}$ dan limfosit B. (Arlian, 2014)

Tungau skabies memicu sekresi anti-inflammatory cytokine interleukin-1 receptor antagonist (IL-1ra) dari sel fibroblas dan keratinosit pada model kulit manusia. IL-1ra menghambat aktivitas sitokin proinflamasi IL-1 dengan mengikat reseptor IL-1 yang terdapat pada banyak sel termasuk sel limfosit $\mathrm{T}$, sel limfosit B, natural killer cell, makrofag dan neutrofil. Ekstrak tungau skabies mengandung molekul yang menekan ekspresi molekul adhesi interselular dan vaskular yaitu intercellular adhesion molecule-1 (ICAM-1) dan vascular cell adhesion molecule-1 (VCAM-1) serta E-selectin oleh kultur sel endotel mikrovaskular kulit manusia. Supresi tersebut akan menghambat atau menurunkan ekstravasasi limfosit, neutrofil dan sel lain ke dalam dermis sehingga mengganggu respons pertahanan hospes. (Morgan, 2015)

S.scabiei dapat menghambat interaksi ko-stimulasi antara limfosit $\mathrm{T}$ dan sel penyaji antigen (antigen presenting cell) sedangkan ekstrak tungau skabies memicu sel limfosit $\mathrm{T}$ regulator untuk memproduksi IL-10. Sitokin tersebut bekerja sebagai antiinflamasi poten dengan menekan sekresi sitokin proinflamasi lain dan ekspresi molekul major histocompatibility complex II (MHC-II) di permukaan sel penyaji antigen. Pada akhirnya, interaksi kompleks MHC-II antigen dan reseptor limfosit $\mathrm{T}$ yang penting untuk aktivasi dan proliferasi sel limfosit B menjadi sel plasma yang memproduksi antibodi menjadi berkurang atau terhambat. (Sungkar S, 2016)

Sel limpa tikus yang dipajankan ke tungau skabies dan tikus yang divaksinasi ekstrak tungau menunjukkan penurunan ekspresi gen B7-2 (CD86) pada sel limfosit B dan reseptornya serta CD28 pada sel limfosit T. Selain itu ekspresi gen CD40 pada sel limfosit B dan reseptornya, CD40L pada sel limfosit T, mengalami down-regulation. Ko-signal tersebut adalah pendamping coupling kompleks reseptor sel T MHC-II-antigen dalam mengaktivasi sel limfosit B untuk menjadi sel plasma yang dapat memproduksi antibodi. (Morgan, 2015)

Model kulit manusia serta monokultur keratin epidermis dan fibroblas dermis manusia mensekresikan lebih banyak vascular endothelial growth factor (VEGF) sebagai respons terhadap tungau skabies hidup maupun ekstraknya. VEGF meningkatkan vaskularisasi dan jumlah plasma di terowongan epidermis yang dekat dengan mulut tungau sehingga terowongan yang semula kering menjadi kaya air dan nutrisi. Hal tersebut dibuktikan oleh pencernaan antibodi di dalam plasma oleh tungau. Produk tungau skabies dapat menurunkan aktivitas IL-8 di sekitar lesi skabies setelah dua hari. IL-8 adalah kemokin yaitu suatu kemotaktik untuk ekstravasasi neutrofil ke lokasi patogen. Monokultur keratinosit epidermis, fibroblas dermis, sel endotel mikrovaskular kulit, dan sel dendritik yang dipajankan ekstrak tungau skabies menurunkan kadar IL-8 dalam media dibandingkan kontrol. Tungau skabies juga memproduksi protein pengikat IL-8 yang dapat menurunkan kadar IL-8 lokal sehingga menghambat kemotaksis neutrofil. (Mellanby, 2014) 
Inhibitor protease serin yang terdapat di sistem pencernaan tungau dapat mengikat kaskade komplemen di dalam plasma dan menghentikan ketiga jalur sistem komplemen manusia yaitu jalur klasik, alternatif dan lektin. Aktivasi komplemen hospes dapat melindungi tungau dari kerusakan yang disebabkan komplemen karena tungau skabies menelan plasma. Inhibitor komplemen dapat memudahkan Streptococcus grup A menginfeksi lesi skabies dan menyebabkan pioderma. Selain mampu melakukan down-regulation, respons protektif hospes, ekstrak tungau dan tungau hidup juga dapat melakukan up-regulation sekresi sitokin proinflamasi oleh keratinosit, fibroblas dan sel endotel. Oleh karena itu respons hospes yang sesungguhnya merupakan keseimbangan antara kejadian yang memicu respons protektif dengan yang menghambat. Durasi infestasi dan kepadatan tungau berperan dalam mengubah keseimbangan tersebut. (Arlian, 2014)

Gen yang mengekspresikan 28 prekursor IL-1a, IL-1b, prekursor granulocyte macrophage colony stimulating factor (GM-CSF) dan prekursor granulocyte colony-stimulating factor (G-CSF) mengalami up-regulation. Gen IL1F9 diekspresikan 8 kali lipat lebih besar dari kontrol dan merupakan gen tertinggi kedua yang mengalami up-regulation. Gen tersebut mengkode protein dari keluarga sitokin IL-1. Tungau skabies memicu up-regulation ekspresi gen IL-1 receptor-like precursor (IL1RL1) dan gen yang paling banyak mengalami upregulation adalah KRT37. Gen tersebut adalah keluarga gen keratin yang mengkode protein keratin tipe I yang mengalami hetero dimerisasi dengan keratin tipe II untuk membentuk rambut dan kuku. Gen LCE3C mengkode protein late cornified envelope protein 3C mengalami upregulation. Gen LCE lain mengalami up-regulation namun gen yang mengkode keratin mengalami down-regulation. Gen KRT13 dan KRT15 yang mengkode type I cytokeratins juga mengalami down-regulation. Gen KRT77 yang mengkode type II keratin, protein type II cytoskeletal 1b, mengalami down-regulation dan KRT1 menurun. Anggota keluarga gen ankyrin dan sitokrom P450 juga menurun. Kelompok gene ontology (GO) menyediakan rangka kerja yang bermanfaat dalam menjelaskan komponen selular $(\mathrm{C})$, proses biologis $(\mathrm{P})$, dan fungsi molekular (F) yang dipengaruhi oleh ekspresi serangkaian gen. Terdapat 25 kelompok GO yang memiliki presentasi tertinggi perubahan ekspresi gen oleh HSE yang diinfestasi tungau. Dari 15 kelompok gen yang diekspresikan, 10 gen terlibat dalam regulasi sekresi sitokin. Kelompok gen GO yang terlibat dalam aktivitas sitokin melibatkan 23 gen untuk sitokin yang berubah pada HSE yang dipajankan tungau hidup. Enam kelompok mengandung gen untuk ekspresi IL-1a dan 14 kelompok mengandung gen untuk ekspresi IL-1b. Sebanyak $11 \%$ gen yang terlibat dalam keratinisasi dan $9 \%$ gen dalam kelompok GO taksis mengubah ekspresi sebagai respons terhadap tungau skabies hidup. (Morgan, 2015)

Sebagai respons terhadap pembuatan terowongan oleh tungau, HSE mengubah ekspresi banyak gen yang berhubungan dengan respons imun, respons pertahanan, aktivitas sitokin, taksis, respons terhadap organisme lain dan adhesi sel. Gen yang terlibat dalam perkembangan epitel dan keratinisasi juga mengalami perubahan ekspresi sebagai respons terhadap tungau skabies. (Sungkar S, 2016)

Dibandingkan dengan HSE yang diinokulasi tungau hidup, Morgan et al (2015) melaporkan hanya 15 gen yang mengalami perubahan ekspresi pada HSE yang dipajankan ekstrak tungau skabies. Tidak ada gen yang mengalami down-regulation secara signifikan. Delapan dari 15 gen yang mengalami up-regulation juga diekspresikan lebih oleh HSE yang dipajankan tungau hidup dibandingkan ekstrak tungau. Gen tersebut adalah KRT37, IL1F9, ARG1, AC011443.6 dan LCE3C. Ekspresi gen IL1B tidak berubah dibandingkan kontrol. Gen pada kelompok GO sitokin yang paling banyak berubah ekspresi adalah gen pengkode IL-1a, 
IL-1b, IL-11, IL-16, IL-20, IL- 23, dan transforming growth factor-a (TGFa). Seluruhnya adalah sitokin yang memiliki berbagai fungsi dan dihubungkan dengan inflamasi kulit. IL-16 dihasilkan oleh keratinosit dan merupakan chemotactic yang merangsang migrasi sel limfosit $\mathrm{T}$ CD4+, monosit dan eosinofil. Ekspresi gen sitokin IL-16 mengalami down-regulation setelah pajanan tungau yang menyebabkan keterlambatan respons inflamasi pada awal infestasi skabies. IL-20 meregulasi proliferasi dan diferensiasi keratinosit selama inflamasi. Oleh karena itu, upregulation IL-20 mungkin berkontribusi dalam proliferasi keratinosit, hiperkeratosis, pembentukan skuama dan krusta seperti pada skabies kronik.

Secara in vivo IL-23 diproduksi oleh keratinosit dan sel dendritik. Efek patologis di kulit dimediasi oleh sitokin Th17. Penghambatan IL-17 dan IL-23 mungkin dapat menekan penyakit inflamasi kronik. Karena gen IL-20 dan IL-23 banyak diekspresikan sebagai respons terhadap tungau skabies hidup maka timbul pertanyaan: apakah penghambatan sitokin dapat menjadi metode pengobatan baru dengan menurunkan inflamasi dan rasa gatal pada skabies. Gen kemokin yang ekspresinya paling banyak berubah adalah CCL3, CCL5, CCL20, CXCL2, CXCL5, CXCL6, CXCL12, dan CXCL14. Semua gen tersebut adalah anggota kelompok GO taksis namun sekresinya tidak diteliti. Ekspresi gen tersebut konsisten dengan penemuan histologis lesi skabies yang menunjukkan infiltrasi sel inflamasi yang terkonsentrasi di sekitar mulut dan anus skabies. Hal tersebut menunjukkan bahwa molekul efektor berhubungan dengan sekresi saliva dan feses serta memicu respons kemotaktik. Walaupun demikian, CXCL12 dan CXCL14 mengalami down-regulation yang merugikan tungau saat tungau mencoba menginfestasi kulit hospes. Kelompok GO lain dengan banyak gen yang menerima dampak tungau skabies adalah kelompok keratinisasi. Hal tersebut berhubungan dengan munculnya hiperkeratosis, krusta dan skuama pada skabies. Sepuluh gen keratinisasi mengalami upregulation. Kebanyakan gen tersebut berhubungan dengan kornifikasi epidermis menjadi stratum korneum. KRT37 merupakan gen yang ekspresinya meningkat paling banyak. Perubahan pada gen tersebut mungkin berhubungan dengan penyembuhan epidermis yang dirusak oleh tungau. (Morgan, 2015)

Banyak gen dalam keratinosit dan fibroblas kulit diekspresikan secara berbeda dalam merespons tungau skabies yang hidup di dalam kulit baik produk maupun aktivitas fisiknya. Keratinosit dan fibroblas dalam HSE merespons invasi tungau dan produknya dengan respons pro-inflamasi. Secara in vivo, banyak jenis sel lain yang merespons keberadaan tungau skabies dan produknya serta substansi yang diproduksi oleh keratinosit dan fibroblas dalam merespons tungau. Terdapat interaksi yang kompleks antar jenis sel termasuk antigen-presenting cells dan limfosit selama merespons skabies. Kebanyakan interaksi tersebut masih belum diketahui dan dari yang sudah diketahui melibatkan sel endotel, sel langerhans, sel dendritik dan limfosit. Tungau skabies mampu memodulasi banyak aspek respons imun hospes yang menjamin keselamatan dan kehidupannya. (Mellanby, 2014)

\section{PENUTUP}

Human skin equivalents (HSE) adalah substitusi kulit yang terdiri atas stratum korneum serta keratinosit yang berproliferasi dan dermis yang terdiri atas fibroblas di dalam matriks kolagen yang memiliki properti kulit manusia. HSE memiliki properti fisik mirip epidermis dan dermis kulit manusia normal. Penelitian menggunakan HSE menunjukkan modulasi sekresi 
sitokin, ekspresi molekul adhesi sel, dan ekspresi gen sebagai respons terhadap molekul ekstrak tungau skabies.

\section{DAFTAR PUSTAKA}

Arlian LG, Morgan MS. Serum antibody to S. scabiei and house dust mite prior to and during infestation with S. scabiei. Vet Parasitol. 2014;90(4):315-26.

Departemen Kesehatan RI. Profil Kesehatan Indonesia Tahun 2017. Diunduh dari http://www.depkes.go.id/pusdatin [Disitasi 28 Juli 2020]

Mellanby K. Immunology of scabies. In: Orkin M, Maibach, Parish, Schwartzman, eds. Scabies and pediculosis. Philadelphia: JB Lippincott Co,2014; 84-7.

Morgan MS, Arlian LG, Markey MP. Sarcoptes scabiei mites modulate gene expression in human skin equivalents. PLos One. 2015;8(8):E71143.

Ratnasari AF, Sungkar S. Prevalensi skabies dan faktor-faktor yang berhubungan di Pesantren X, Jakarta Timur. EJKI. 2015;1:2

Sungkar S. Skabies, Etiologi, Patogenesis, Pengobatan, Pemberantasan, dan Pencegahan. Jakarta : Badan Penerbit Fakultas Kedokteran Universitas Indonesia; 2016.

World Health Organization. Report of the tenth meeting of the WHO Strategic and Technical Advisory Group for neglected tropical disease. 2017. Diunduh dari http://www.who.int/neglected_disease/NTD_STAG_report_2017.pdf?ua=i [Disitasi 28 Juli 2020] 